\title{
PARAMETERS FOR AREAS OF PRE-COMMERCIAL THINNINGS CONDUCTED IN PRIVATE FORESTS DURING 2007 - 2017
}

\author{
Raimonds Bermanis, Inga Straupe, Andra Zvirbule \\ Latvia University of Life Sciences and Technologies, Latvia \\ raimonds.bermanis@mkpc.llkc.lv
}

\begin{abstract}
The paper covers analysis of pre-commercial thinning performed in private forests over the period of 2007 - 2017 . Since 2007, permanent and considerable European Union subsidies for pre-commercial thinning have been available, resulting in a significant increase in area of thinned young stands in private forests. The aim of this research is ascertain pre-commercial thinning activity depending on the type of forest owner (individuals, legal persons or local municipality), forest stand type (forest stand or plantation) and origin (natural or artificial) as well as the forest owner's intention to apply for European Union subsidies. Data analysed were obtained from Forest State Registernational data base, managed by state authority State Forest Service and continued analysis comprise two main topics - ascertain amount and type of young stands owned by different type of private forest owners and amount and type of conducted pre-commercial thinnings. Forest owners legal persons have significantly higher amount $47 \%$, of young plantation forest and forest stands from the total forest stands area, compared to other type of forest owners. The highest intensity of thinnings was conducted in plantation forests of artificial origin owned by legal and physical persons, also forest stands with artificial origin owned by physical persons. The current period for European Union Rural development programme will be over in 2020; therefore, it is important to analyse the existing approach of granting subsidies to forestry and find the improvement necessary for the planning period from the year 2021 .
\end{abstract}

Key words: private forestry, pre-commercial thinning, plantation forest, young forest stands.

\section{Introduction}

Private forests owned by individual persons (hereafter - physical persons), legal persons and local municipalities compose $51 \%$ of the total forest area in Latvia. Private persons own 1436138 ha area of forest stands, of which 925474 ha (64\%) belong to physical persons, 423048 ha (30\%) to legal persons and 87616 ha $(6 \%)$ to local municipalities. Significant differences exist concerning the average size of forest property among physical and legal persons: 7.89 ha for physical persons and 79.91 ha for legal persons (Donis, 2016), and it is the reason for the different aims of forest management, implemented methods and frequency of management activities. The proportion of the ownership of forest area between physical persons and legal persons continued to change over the period of 2013 - 2018, the area owned by private physical persons had declined by $1.7 \%$, but the area owned by legal persons had increased by $24.45 \%$ (Donis, 2014; 2016), partly because the areas were purchased by legal persons and to some extent by the state forest management company 'Latvijas valsts meži’ (Latvian state forests) (Mičāne, 2018). A significant majority of European Union (hereafter EU) subsidies for private forestry since 2006 has been available from the European Agricultural Fund for Rural Development and is dedicated to precommercial thinnings, cleanings after afforestation and after forest regeneration in certain cases and for small scale investments - purchase instruments for thinning as chainsaws and bush cutter saws (Benga, 2016). Over the period of national Rural development programme 2007 - 2013, subsidies were granted for pre-commercial thinnings in total area of 64624 ha, and finances allocated for this purpose $15.23 \mathrm{mln}$ euro (Benga, 2016), as regards the annual average area of clearcuts in private forests compile 25000 ha (State Forest Service, 2017). Assignation of EU subsidies for pre-commercial thinning was the main reason for a steep increase in the thinned area in private forests, from 5.8 thsd. ha in 2006 up to 83.5 thsd. ha in 2013 (Ministry of Agriculture, 2017). Thinning of young stands is a technique used in forest stands or cuttings in which trees have been planted, sowed or naturally regenerated with the aim of ensuring the formation of qualitative, productive and vital tree stands. Thinnings are carried out according to the necessity in $4-20$ year old stands, occasionally also in older stands, which are divided into levels of work performing difficulty according to the height and diameter of competing trees. The thinning of young stands encourages the development of species best suited for forest growth conditions. In addition, thinnings increase the future forest productivity and the value of the trees that are left, which depend on the genetic characteristics of the plants or seeds. By properly thinning young stands, the trees to be left gain larger growing space and the duration of forest rotation cycle decreases, i.e. - the desired result is obtained on average $10-20$ years faster (if the stand is planned to be harvested according to the diameter - when the dominant tree species have reached the diameter of the final felling), and the trees are with straight and large trunks. As a result of the thinnings carried out in young stands, sound, sustainable and uniform target species stands are created. (State Forest Service information, pre-commerial thinning, http://www.vmd.gov. lv/valsts-meza-dienests/statiskas-lapas/-meza- 
apsaimniekosana-/jaunaudzu-kopsana?nid=1681). According to the national legislation, EU subsidies for pre-commercial thinning might be applicable for young stands till the age of 40 years for coniferous stands and deciduous stands of common oak (Quercus robur L.), and ash (Fraxinus excelsior $\mathrm{L}$.) if the height of the trees is less than 10 meters. Forest stands of grey alder (Alnus incana (L.) Moench.) conform to young stand status till the age of 10 years, but the stands of other tree species conform to young stands status till the age of 20 years (The Cabinet of Ministers of the Republic of Latvia, No 455, 2015). National regulations for forest regeneration, afforestation and forest plantation require obligations for forest owners to carry out pre-commercial thinnings for coniferous young stands at least once up to the stand age of 10 years, but for deciduous young stands up to the age of 5 years. (The Cabinet of Ministers of the Republic of Latvia, Regulation No 308, 2012). According to the data of the State Forest Service, the total area of the young stands thinned in the year 2016 was 68.6 thousand ha, from which 35.9 thousand ha were state forests and 32.7 thousand ha were other owners' forests. Silver birch (Betula pendula Roth.) and downy birch (Betula pubescens Ehrh.) stands turned out to be the most thinned young stands (33\%), followed by young Norway spruce (Picea abies (L.) H.Karst.) stands (28\%) and young Scots pine (Pinus sylvestris L.) stands (21\%), the remaining tree species young stands which were thinned accounted for $18 \%$. (State Forest Service information, http://www.vmd. gov.lv/valsts-meza-dienests/statiskas-lapas/-mezaapsaimniekosana-/jaunaudzu-kopsana?nid=1681). The objective of this study was to investigate the process of pre-commercial thinnings in private forests, the intensity of the activity depending on the origin of the forest stand: either natural or artificial, type of forest stand: either a forest stand or a plantation forest, forest owner: either physical, legal person or local municipality and their intention to apply for EU subsidies for pre-commercial thinning measure. The tasks of the research were to identify the pros and cons for the pre-commercial thinnings and the significance of EU subsidies available for the specific activity.

\section{Materials and Methods}

The data used for this study were obtained from the State Forest Service - the state authority that supervises forest management in all types of forests, gathers and stores forest inventory data in data base Forests State Register, for all types of forest owners and is one of the organisations which to some extent grants EU subsidies to private forest owners. Forest State Register is based on forest inventory data, submitted from forest owners at least once per 20 years, afterwards annually updates forest stand main parameters such as growing stock, age, diameter, height etc., and store management operations done. The data analysed in this study cover information of young stands in ha, owned by physical and legal persons and local municipalities, in breakdown by tree species, origin and type of forest stand. State forests were excluded from the study due to their long term and by the government approved forest management planning approach, also respecting rules that EU subsidies might not be dedicated for the state forest management. The Law on Forest defines young stands in terms of age and tree species - for Scots pine and Norway spruce they are stands up to the age of 40 years, for silver birch and downy birch, aspen (Populus tremula L.) and black alder (Alnus glutinosa (L.) Gaertn.) - stands up to the age of 20 years, but for grey alder up to the age of 10 years. The same criteria in this study were used for plantation forests. A plantation forest is defined as forest stands established through afforestation, intended for specific purposes by The Law on Forests. Afforestation may occur by natural or artificial processes and for the forest plantation significant forest management rules, such as cutting age, diameter and regenerations regulations are not applicable. The criteria for young stands mentioned before and of six main widespread tree species (Scots pine, Norway spruce, Birch species, aspen , black alder and grey alder) were included in this study and they covered $98.5 \%$ of forest stands as the main tree species (Ministry of Agriculture, 2017). These data were prepared for the study by the State Forest Service as of February 2018. To assess areas where pre-commercial thinnings were conducted in the period of 2007 - 2017, the data from the State Forest Service cover information on areas for annual pre-commercial thinning, main tree species, origin, type of forest stand and type of forest owner on status on September 2017. Additionally indicated is the area in ha for the intention of forest owner to apply for EU subsidies for pre-commercial thinning measure: approved forest management plans to apply for EU subsidies. The task of the State Forest Service is to approve the forest management process documentation for the forest owner who wants to apply later for EU subsidies at payment Agency - Rural Support Service. To study the amount and age of forest stands, where pre-commercial thinnings were conducted, the State Forest Service delivers the data on the period of 2007-2017, but for the reason that basic data for certain share of forest properties is continuously changed through new forest inventories, new forest owners and inventory data are annually updated, attributes of forest stand display current status with remarks on management activities in the past. Therefore, the data of age distribution may be used to show only percentages, not certain areas in ha. During the 
study also the percentage of the conducted thinnings from total areas of young stands for certain type of owner, stand type, origin and intention to apply for EU subsidies were calculated. However, the thinned areas may overlap in time (for instance the same forest stand likely thinned in the years 2007, 2010 and 2014); therefore, the area parameter for thinned area is not absolute and unique, and the calculated percentage indicates the activity of a certain type of management as a coefficient.

\section{Results and Discussion}

Characteristics of young plantation forests and forest stands owned by private forest owners

Private forest owners (legal, physical, local municipalities) totally own young plantation forest stands covering the area of 33059 ha, and young forest stands covering the area of 452176 ha. In total, 485 235 ha, accounting for $33.78 \%$ of the total forest stand areas are owned by private forest owners in 2018. The analysis of the data concludes that physical persons own 14704 ha of young plantation forest stands and 256226 ha of young forest stands, respectively 1.6\% and $27.7 \%$ from the total forest stand area for physical persons. Legal persons own 18037 ha of young plantation forest stands and 180578 ha of young forest stands, respectively $4.3 \%$ and $42.68 \%$ from the total forest stand area for legal persons.

Local municipalities own 70.6 ha of young plantation forest stands and 15371 ha of young forest stands, respectively $0.08 \%$ and $17.54 \%$ from the total forest stand area for local municipalities.
The forest owners who are legal persons own significantly larger amount of young plantation forest and forest stands as a component of total forest stands area, for young forest stands reaching even $42.68 \%$. During the last decade, legal persons have been active in purchasing forest properties from physical persons, which mostly were cutovers and young stands, as well as abandoned agricultural lands, which have been later afforested as plantation forest or forest stands. The results of the research conducted before, acknowledge higher productivity for birch species on agricultural lands compared to birch stands of natural origin (Liepiņš, 2011), which may be one of objective purposes for afforestation progress. The analysis of the age distribution of plantation forests for all types of private forest owners for four decades is the following: for the $1^{\text {st }}$ decade $-49 \%$, $2^{\text {nd }}$ decade $-48 \%$, $3^{\text {rd }}$ decade $-3 \%$, $4^{\text {th }}$ decade $-0 \%$, which approves the authors' previous estimations.

Forest owners - legal persons have significantly higher percentage of plantation forest of artificial origin - $67 \%$ versus $38 \%$ for physical persons. Different tree species composition for artificial plantation forests was observed among different types of owners - Norway spruce tree plantation forest accounts for $70 \%$ among legal persons versus $57 \%$ among physical persons. For plantation forest of natural origin among the type of forest owners similar tree composition was observed - stands dominated by birch species, Scots pine and Norway spruce trees. (Table 1).

Table 1

Division of young plantation forest stands by origin, main tree species and type of private forest owner

\begin{tabular}{|c|c|c|c|c|}
\hline \multirow{2}{*}{ Type of owner* } & \multicolumn{2}{|c|}{ Origin of plantation forest } & \multicolumn{2}{|c|}{ Tree composition } \\
\hline & Type of origin & $\%$ of area & Tree species** & $\%$ of area occupied \\
\hline \multirow{6}{*}{ Physical } & \multirow{3}{*}{ Natural } & \multirow{3}{*}{62} & Birch species & 42 \\
\hline & & & Scots pine & 24 \\
\hline & & & Norway spruce & 17 \\
\hline & \multirow{3}{*}{ Artificial } & \multirow{3}{*}{38} & Norway spruce & 57 \\
\hline & & & Birch species & 32 \\
\hline & & & Scots pine & 8 \\
\hline \multirow{6}{*}{ Legal } & \multirow{3}{*}{ Natural } & \multirow{3}{*}{33} & Birch species & 41 \\
\hline & & & Norway spruce & 19 \\
\hline & & & Scots pine & 19 \\
\hline & \multirow{3}{*}{ Artificial } & \multirow{3}{*}{67} & Norway spruce & 70 \\
\hline & & & Birch species & 23 \\
\hline & & & Scots pine & 3 \\
\hline
\end{tabular}

* owner type 'local municipalities' is excluded due to the low area of plantation forest.

** top 3 tree species referred. 
Division of young forest stands by origin, main tree species and types of private forest owner

\begin{tabular}{|c|c|c|c|c|}
\hline \multirow{2}{*}{ Type of owner } & \multicolumn{2}{|c|}{ Origin of forest stands } & \multicolumn{2}{|c|}{ Tree composition } \\
\hline & Type of origin & $\%$ or area & Tree species* & $\%$ of area occupied \\
\hline \multirow{6}{*}{ Physical } & \multirow{3}{*}{ Natural } & \multirow{3}{*}{80} & Birch species & 43 \\
\hline & & & Aspen & 25 \\
\hline & & & Norway spruce & 14 \\
\hline & \multirow{3}{*}{ Artificial } & \multirow{3}{*}{20} & Norway spruce & 63 \\
\hline & & & Birch species & 20 \\
\hline & & & Scots pine & 15 \\
\hline \multirow{6}{*}{ Legal } & \multirow{3}{*}{ Natural } & \multirow{3}{*}{72} & Birch species & 46 \\
\hline & & & Aspen & 24 \\
\hline & & & Norway spruce & 11 \\
\hline & \multirow{3}{*}{ Artificial } & \multirow{3}{*}{28} & Norway spruce & 68 \\
\hline & & & Birch species & 16 \\
\hline & & & Scots pine & 14 \\
\hline \multirow{6}{*}{ Local municipalities } & \multirow{3}{*}{ Natural } & \multirow{3}{*}{48} & Birch species & 37 \\
\hline & & & Scots pine & 28 \\
\hline & & & Aspen & 19 \\
\hline & \multirow{3}{*}{ Artificial } & \multirow{3}{*}{52} & Scots pine & 54 \\
\hline & & & Norway spruce & 35 \\
\hline & & & Birch species & 10 \\
\hline
\end{tabular}

* top 3 tree species referred.

Regarding the young forest stands of natural origin, the highest proportion belongs to physical persons $-80 \%$, while legal persons have slightly smaller proportion $-72 \%$ of total young stand forest areas (Table 2). Local municipalities own larger amount of young forest stand area of artificial origin versus natural origin. Regarding the young stands of natural origin, no significant changes in tree species composition were found, for all types of private forest owners in this category the two dominant tree species are birch and aspen.

Previous researches done on this subject acknowledge an increase in birch stand area in Latvia that considerably affects the overall Latvian forest ecosystem (Daugaviete et al., 2013). Regarding the tree composition of young forest stands of artificial origin for physical and legal persons - Norway spruce definitely dominated by $-63 \%$ and $68 \%$ of total area in this category. Different tree composition was observed for young stands of local municipalities, where artificially regenerated forest stands consist of $54 \%$ of Scots pine. The analysis of age distribution for young forest stands for all types of private forest owners over four decades is the following: $1^{\text {st }}$ decade $34 \%$, $2^{\text {nd }}$ decade $-56 \%$, $3^{\text {rd }}$ decade $-4 \%$, $4^{\text {th }}$ decade 6\% (State Forest Service information, 2018).
Characteristics of pre-commercial thinnings conducted and EU subsidies intended for this purpose

For the period of 2007 - 2017, the area of totally thinned young plantation forest stands by private forests owners' (legal, physical, local municipalities) was 18495 ha, but that of young forest stands was 194 617 ha. In total, 213112 ha, accounting for $43.92 \%$ of total young plantation and forest stands area were included in this study. The research conducted previously refers to the importance of pre-commercial thinning in grey alder stands. Grey alder is considered to be one of the most prospective local tree species due to its productivity and forestry characteristics. Most of grey alder forest stands are of natural origin great proportion of them have been formed as a result of overgrown agricultural territories which have not been cultivated. Poorly managed grey alder forest stands of natural origin contain trees with poor trunk qualities and their productivity does not reflect the real productivity potential of this tree species. Grey alder is considerably faster growing than black alder. (Liepiņš \& Liepiņš, 2010). Forest owners physical persons thinned young plantation forest stands in the area of 8320 ha and young forest stands over the area of 108302 ha, respectively $56.58 \%$ and $42.27 \%$ from the total young plantation and forest stand areas 


\section{The intensity of pre-commercial thinnings and use of EU subsidies} by the origin and type of stand and forest owner

\begin{tabular}{|c|c|c|c|c|c|}
\hline \multirow[b]{2}{*}{ Type of owner } & \multicolumn{2}{|c|}{ Origin of stands } & \multirow{2}{*}{$\begin{array}{l}\text { Intensity of } \\
\text { thinnings, \% }\end{array}$} & \multirow{2}{*}{$\begin{array}{l}\text { Intensity of thinnings, } \\
\text { \% with EU subsidies } \\
\text { (from total area) }\end{array}$} & \multirow{2}{*}{$\begin{array}{l}\text { Amount of thinnings with } \\
\text { EU subsidies, \% (from } \\
\text { totally thinned area) }\end{array}$} \\
\hline & $\begin{array}{l}\text { Type of } \\
\text { origin }\end{array}$ & $\begin{array}{l}\text { Type of } \\
\text { stand }\end{array}$ & & & \\
\hline \multirow{4}{*}{ Physical } & \multirow{2}{*}{ Natural } & Forest & 35.99 & 8.12 & 22.57 \\
\hline & & Plantation & 17.57 & 4.71 & 26.83 \\
\hline & \multirow{2}{*}{ Artificial } & Forest & 50.02 & 15.76 & 31.51 \\
\hline & & Plantation & 99.17 & 29.28 & 29.52 \\
\hline \multirow{4}{*}{ Legal } & \multirow{2}{*}{ Natural } & Forest & 34.36 & 4.71 & 13.71 \\
\hline & & Plantation & 15.06 & 2.59 & 17.17 \\
\hline & \multirow{2}{*}{ Artificial } & Forest & 35.75 & 7.63 & 21.35 \\
\hline & & Plantation & 61.32 & 8.98 & 14.64 \\
\hline \multirow{4}{*}{ Municipalities } & \multirow{2}{*}{ Natural } & Forest & 24.11 & 2.71 & 11.23 \\
\hline & & Plantation & 0 & 0 & 0 \\
\hline & \multirow{2}{*}{ Artificial } & Forest & 21.00 & 3.98 & 18.96 \\
\hline & & Plantation & 0 & 0 & 0 \\
\hline
\end{tabular}

for physical persons. Legal persons thinned young plantation forest stands over the area of 10173 ha and young forest stands over the area of 78542 ha, respectively $56.4 \%$ and $43.49 \%$ from total young plantation and forest stand areas for legal persons. Local municipalities thinned young plantation forest stands over the area of 0.00 ha and young forest stands over the area of 7773 ha, $50.56 \%$ from young forest stand area for local municipalities respectively. The highest intensity of pre-commercial thinnings was found out for forest plantations of artificial origin $61.32 \%$ for legal persons and $99.17 \%$ for physical persons. Research done reveal that naturally emerged stand might be often transformed into productive stands. Different management methods may be applied to create productive forest stands on naturally afforested agricultural lands. Thinning of young stands of natural origin is strongly recommended as a management method to improve the productivity of future stands. (Jogiste, Vares, \& Sendros, 2003). Forest stands and plantation forests of artificial origin owned by physical persons have the highest intensity in terms of the use of EU subsidies - $15.76 \%$ and $29.28 \%$ respectively (Table 3 ).

The analysis of the age distribution for all types of private forest owners for four decades of thinned plantation forests is for the 1st decade - $70 \%$, 2nd decade - 29\%, 3rd decade - 1\%, 4th decade $0 \%$, and for thinned young forest stands for the 1 st decade $-29 \%$, 2nd decade $-69 \%$, 3rd decade - 2\%, 4 th decade $-0 \%$, respectively. From the total amount of thinnings conducted, physical persons were most active to apply for EU subsidies - from $22.57 \%$ up to $31.51 \%$ depending on the type of stand and type of origin. Legal persons applied for EU subsidies in $21.35 \%$ of the area thinned for artificially created forest stands, which is the highest percentage. Local municipalities have the lowest percentage of thinned areas from young forest stands of both origins, also having the lowest intensity in applying for EU subsidies.

\section{Conclusions}

Forest owners - legal persons have significantly higher percentage $-47 \%$, of young plantations forest and forest stands from the total area of forest stands compared to other type of forest owners. Forest owners - physical persons mostly create plantation forests through the natural afforestation process $(62 \%$ of all plantation forest area), while forest owners legal persons in $67 \%$ of the area have plantation forest of artificial origin. The origin of young forest stands is definitely dominated by natural process, in $80 \%$ for physical persons and in $72 \%$ for legal persons from the total young stand forest area. The study of the intensity of pre-commercial thinning conducted in terms of percentage of total young forest plantation or forest stand area leads to the conclusion that plantation forests of artificial origin have the highest thinning intensity, particularly for physical persons, followed by forest stands of artificial origin and forest stands of natural origin. Plantation forests have the highest thinning intensity in the $\mathrm{I}^{\text {st }}$ age decade, mostly stands of natural origin and owned by physical 
persons, while forest stands in the $2^{\text {nd }}$ age decade have the highest thinning intensity, mostly stands of both origin and owned by all type of private forest owners. In the majority of cases physical persons apply for the EU subsidies particularly for thinning the areas of artificial origin (up to $31.51 \%$ ) and also legal persons in most cases apply for EU subsidies for young stands of artificial origin (up to 21.35\%). Pre-commercial thinnings were conducted in the highest intensity in young forest stands of artificial origin, particularly in the plantation forest category. Research may conclude on highly commercial approach for plantation forests, also similar attitude to forest stands of artificial origin. In forest area overwhelmed regeneration type is natural, and precommercial thinning in those areas were conducted in moderate low intensity. To clarify the proportion of conducted pre-commercial thinnings related to the stand establishment processes and stand maintenance, further research shall be carried out.

\section{Acknowledgments}

We are grateful to the State Forest Service and senior specialist Janis Uzulis for the selection of data used for this study.

Research was supported by Latvian University of Life Sciences and Technologies grant 'The strengthening of scientific capacity'.

\section{References}

1. Benga, E. (2013). Ex-ante novērtējums Lauku attīstības programmai 2014-2020 (Ex-ante Assessment of the Rural Development Programme 2014-2020). Institute of Agricultural Resources and Economics. Retrieved March 14, 2018, from: https://www.zm.gov.lv/public/files/CMS_Static_Page_Doc /00/00/00/39/80/Ex_ ante_gala_2014.pdf. (in Latvian).

2. Benga, E. (2016). Lauku attīstības programma 2007-2013. Ex post novērtējums. (Rural Development Programme 2014-2020. Ex-post evaluation). Institute of Agricultural Resources and Economics. Retrieved March 14, 2018, from: http://www.arei.lv/sites/arei/files/files/lapas/LAP\%202007-2013\%20ex-post\%20 nov\%C4\% 93rt\%C4\%93 jums.pdf. (in Latvian).

3. Daugaviete, M., Korica, A., Siliņš, I., Bārdulis, A., Bārdule, A., Daugavietis, U., \& Spalvis, K. (2013). Minerālvielu aprite bērza jaunaudzēs dažādos augšanas apstāklos un to ietekme uz audžu vitalitāti. (Mineral nutrient turnover in young stands of birch in different forest growing condition and soil types). Mežzinātne, 27(60), 17-35. (in Latvian).

4. Donis, J. (2014). Privāto mežu apsaimniekošanas un meža īpašumu konsolidācijas un kooperācijas procesa monitorings (Monitoring of private forest management, holding consolidation and cooperation). Retrieved March 14, 2018, from: https://www.zm.gov.lv/public/ck/files/ZM/mezhi/MAF/PARSKATS Privato_mezu_apsaimniekosana_Silava.pdf. (in Latvian).

5. Donis, J. (2016). Privāto mežu apsaimniekošanas un meža īpašumu konsolidācijas un kooperācijas procesa monitorings (Monitoring of private forest management, holding consolidation and cooperation). Retrieved March 14, 2018, from: https://www.zm.gov.lv/public/ck/ files/MAF2016priv_v2ofic.pdf. (in Latvian).

6. Cabinet of Ministers of the Republic of Latvia. (2012). Meža atjaunošanas, meža ieaudzēšanas un plantāciju meža noteikumi Nr. 308. (Regulations No 308 of Forest regeneration, afforestation and plantation forest). Retrieved March 14, 2018, from: https://likumi.lv/doc.php?id=247349. (in Latvian).

7. Cabinet of Ministers of the Republic of Latvia. (2015). Kārtība, kādā piešķir, administrē un uzrauga valsts un Eiropas Savienības atbalstu pasākuma 'Ieguldījumi meža platību paplašināšanā un mežu dzīvotspējas uzlabošanā' '̄stenošanai, noteikumi Nr. 455. (Regulations No 455 of order to grant, administer and control state and EU support for measure 'Investments to extend forest areas and improving forest viability'). Retrieved March 14, 2018, from: https://likumi.lv/ta/id/275943-kartiba-kada-pieskir-administre-unuzrauga-valsts-un-eiropas-savienibas-atbalstu-pasakuma-ieguldijumi-meza-platibu-paplasinasana. (in Latvian).

8. Jogiste, K., Vares, A., \& Sendros, A. (2003). Restoration of former agricultural fields in Estonia: comparative growth and naturally regenerated birch. Forestry Vol. 76 (2), pp. 209-218.

9. Mičāne, I. (2018). "Latvijas valsts meži” no privātīpašniekiem pērn nopirkuši 1618 ha meža zemes. ("Latvian State forest" purchased 1618 ha forest land from private owners last year). Retrieved March 14, 2018, from: http://aukos.la.lv/latvijas-valsts-mezi-no-privatipasniekiem-pern-nopirkusi-1618-ha-mezazemes. (in Latvian).

10. Ministry of Agriculture Latvia (2017). Latvian Forest Sector in Facts \& Figures, 2018. Retrieved March 14, 2018, from: https://www.zm.gov.lv/public/ck/files/skaitlifakti_EN_2018web.pdf.

11. Liepiņš, K., \& Liepiņš, J. (2010). Baltalkšņa (Alnus incana L. (Moench)) un melnalkšņa (Alnus glutinosa L.) ietvarstādu augšanas rādītāji stādījumā lauksaimniecības augsnēs (Field performance of 
grey alder (Alnus incana L. (Moench) and common alder (Alnus glutinosa L.) container seedlings in experimental plantation on former farmland). Mežzinātne, 21(54), 4-15. (in Latvian).

12. Liepiņš, K. (2011). Kārpainā bērza (Betula pendula Roth.) jaunaudžu augšanas gaita stādījumos lauksaimniecības augsnēs Latvijā (Growth of silver birch (Betula pendula Roth.) in plantations on farmlands in Latvia). Mežzinātne, 23(56), 3-14. (in Latvian).

13. Parliament of the Republic of Latvia. (2000). Law on Forests. Retrieved March 14, 2018, from: https://likumi.lv/ta/en/id/2825-law-on-forests.

14. State Forest Service. (2017). Pārskats par koku ciršanu 2017. gadā. (Report on tree logging in 2017). Retrieved March 14, 2018, from: http://www.vmd.gov.lv/valsts-meza-dienests/statiskas-lapas/publikacijasun-statistika/statistikas-parskati?nid=1810\#jump. (in Latvian). 